\title{
NO-SYNTHASE ACTIVITY AND NITRIC OXIDE CONTENT IN LYMPHOID CELLS OF THYMUS AND SPLEEN OF RATS UNDER CONDITIONS OF DIET-INDUCED OBESITY
}

\author{
L. KOT , V. KONOPELNYUK, K. DVORSHCHENKO, V. VERESCHAKA \\ ESC "Institute of Biology and Medicine", \\ Taras Shevchenko National University of Kyiv, Ukraine; \\ ${ }^{\mathrm{e}}$-mail: kot_lora@ukr.net
}

Received: 10 August 2020; Accepted: 17 May 2021

Metabolic disorders under conditions of obesity are known to be accompanied by systemic inflammation and immune system imbalance while nitric oxide (NO) system is one of the main key links in the immune responses regulation. The aim of the research was to evaluate NO-synthase (NOS) activity and NO content in the cells of thymus and spleen of rats with experimental obesity induced by 14 weeks of high-calorie diet. NO content in cell suspensions was determined using Griess reaction, NOS activity was estimated by $\mathrm{NADPH} \mathrm{H}^{+}+\mathrm{H}^{+}$specific cleavage. It was shown that under conditions of experimental obesity $\mathrm{NO}$ content in cells of thymus and spleen as well as NOS activity in the spleen were decreased with simultaneous increase in both NO content and NOS activity in the serum. The obtained data testify the changes in lymphoid cells functional activity and in organism general adaptive capacity under conditions of obesity.

Ke y wo rd s: nitric oxide, NOS, lymphoid cells, diet-induced obesity.

I $\mathrm{n}$ recent years, the epidemic situation of overweight and obesity has been one of the most important health problems in the world. In economically developed countries, almost $50 \%$ of the population is overweight, with $30 \%$ of them obese.

Characteristic of modern society is growing urbanization, associated with high technological progress, low level of physical activity, malnutrition with increased consumption of energy-rich foods high in fats and preservatives, overeating, so-called "fast food", psychological stress leads to increased obesity among people of all ages.

Disorders of metabolic processes under conditions of obesity, hormonal imbalances cause an inflammatory reaction of the immune system, associated with structural and functional changes in lymphoid organs, accompanied by infiltration of immunocompetent cells, such as T cells, B-cells and macrophages into adipose tissue, and a decrease of regulatory T-lymphocytes [1].

There are structural changes in the spleen, a peripheral organ of the immune system that provides erythrocyte homeostasis, participates in hematopoiesis, metabolism, performs immunobiological, protective functions and is important in the regulation of the immune response. Obesity accelerates the aging-related involution of the thymus (central organ of the immune system), resulting in a decrease in the diversity of $\mathrm{T}$ lymphocytes and a limitation of the immune defense mechanisms [2]. Because intracellular lymphocyte metabolism is based on the ability of these cells to respond rapidly to any changes in homeostasis in the organism, the modulation of the activity of enzyme systems in lymphocytes occurs much earlier than their morphological parameters change.

The functions of immunocompetent cells are determined by their intracellular metabolic processes, among which the key role is played by the processes of free radical oxidation and the formation of reactive oxygen species (ROS) [1]. Excessive free radical generation and prooxidant-antioxidant balance are among the causes of nitric oxide synthase (NOS) activation and nitric oxide (NO) hyperpro-

(C) 2021 Kot L. et al. This is an open-access article distributed under the terms of the Creative Commons Attribution License, which permits unrestricted use, distribution, and reproduction in any medium, provided the original author and source are credited. 
duction. It is known that NO is a potent bioregulator of all cells, organs, systems and organism in general. It is statement that active nitrogen radicals are more potent oxidants compared with oxygen radicals, so nitro-oxidative stress is essential in the mechanism of cell and tissue damage. Instead, both excess and deficiency of $\mathrm{NO}$ generation can be significant in the pathogenesis of many diseases, among which obesity takes an important place [3].

Despite numerous studies on the biochemical mechanisms of action of nitric oxide, today one of the few-studied problems remained is its effect on the state of immunocompetent cells and the immune system in general under conditions of metabolic disorders of organism. Therefore, the aim of our study was to investigate changes in the functioning of the nitric oxide system in cells of thymus and spleen of rats under conditions of experimental dietinduced obesity.

\section{Materials and Methods}

Bioethical statement. The research was conducted according to the general ethical principles, approved by the First National Congress of Ukraine on Bioethics (Kyiv, 2001), the international bioethical principles of "European Convention for the protection of vertebrate animals used for experimental and other scientific purposes" (Strasbourg, France, 1986), and other international agreements and national legislation in this field.

Animals and housing conditions. The experiments were carried out on white male non-linear rats with initial weight of 150-170 g. Animals were kept in the vivarium of the Taras Shevchenko National University of Kyiv, which was accredited in accordance with the "standard rules on ordering, equipment and maintenance of experimental biological clinics (vivarium)". Rats were individually housed in polypropylene cages in an environmentally controlled clean air room, at $18-23^{\circ} \mathrm{C}$, humidity of $40-60 \%$, at $12 \mathrm{~h}$ light/12 h dark cycle.

Study design. During the first week, all animals got free access to water and standard nutrition. On the 8th day, the animals were randomly divided into two representative experimental groups of 10 animals each. The rats of the group 1 (Control) received standard nutrition of vivarium and water ad libitum during 14 weeks of the experimental period. Food consumption was measured daily at the same time (09:00 to 10:00 h) and body weights were determined once a week. In the rats of the group 2 (HCD), the experimental obesity was modeled in accordance [4]. The animals of this group were on a high-calorie diet, which consisted: standard nutrition (60\%), lard (10\%), eggs (10\%), sucrose (9\%), peanut (5\%), dry milk (5\%), vegetable oil (1\%) and water ad libitum for 14 weeks.

Euthanasia of animals was performed by dislocation of the cervical vertebrae, after which the immune organs were removed - thymus and spleen, blood for collecting serum samples and liver.

Isolation of lymphoid cells. Thymocytes from a suspension of thymus cells were isolated by the method [5]. The thymus was pre-cleared of connective tissue and thoroughly rubbed through 4 layers of nylon tissue with the appropriate pore size in the isolation buffer containing $120 \mathrm{mM} \mathrm{NaCl}, 5 \mathrm{mM} \mathrm{KCl}$, $3 \mathrm{mM} \mathrm{Na}_{2} \mathrm{HPO}_{4}, 5 \mathrm{mM}$ HEPES, $10 \mathrm{mM}$ glucose, $4 \mathrm{mM} \mathrm{NaHCO}_{3}, 1.2 \mathrm{mM} \mathrm{CaCl}_{2}$ and $1 \mathrm{mM} \mathrm{MgSO}_{4}$, $\mathrm{pH} 7.4$, receiving the suspension of cells. The cells were washed in isolation medium by centrifugation at $1500 \mathrm{rpm}, 10 \mathrm{~min}$.

Spleen lymphoid cells were isolated by centrifugation on the density gradient Ficoll Pague (Sigma-Aldrich, USA) according to the method [6]. The cleared of connective tissue spleen (450-600 mg) was crushed in a Petri dish with isolation buffer, followed by rubbed through four layers of nylon. After $10 \mathrm{~min}$ of settling, a fraction of lymphoid cells, which consists mainly of small and medium lymphocytes, was isolated from the supernatant by centrifugation at a density gradient Ficoll Paque (density $1.077 \mathrm{~g} / \mathrm{cm}^{3}$ ) $1500 \mathrm{rpm}, 40 \mathrm{~min}$. After the fraction of lymphoid cells formed at the boundary between the ficol and the cell suspension the spleen was carefully collected and washed twice in the isolation medium.

Determination of the number of viable cells was performed by staining with $0.2 \%$ trypan blue in Goryaev's chamber. Viable cells in all experiments were not less than $92 \%$.

Analytical methods. NOS activity was determined by specific cleavage $\mathrm{NADPH}^{+} \mathrm{H}^{+}$according to described methods in [7] and was expressed in nmol $\mathrm{NADPH}^{+} \mathrm{H}^{+}$that oxidized $1 \mathrm{mg}$ of protein in $1 \mathrm{~min}$.

Nitric oxide readily oxidized to nitrite $\left(\mathrm{NO}_{2}^{-}\right)$ and subsequently to nitrate $\left(\mathrm{NO}_{3}{ }^{-}\right)$, which serve as index parameters of NO production. The method for the determination of nitrite levels was based on the Griess diazo reaction. The reduction of nitrates to nitrites was conducted by metallic zinc in the acetic acid solution [8]. The content of nitric oxide was calculated from the amount of nitrite content and 
nitrate reduced to the nitrite by metallic zinc on the calibration curve and expressed in nmol/mg protein. The total protein concentration was measured using Bradford's assay. All spectrophotometry was performed using the devices Smart Spec ${ }^{\mathrm{TM}}$ Plus, BioRad, USA.

Statistical analysis. Statistical analysis of the research results was performed by conventional methods of variation statistics using One-Way ANOVA and $t$-test standard application software package Statistica 8.0. For the analysis of data distribution type, Shapiro-Wilka's criterion was used. When the data were normally distributed, Levan criterion for evaluating the equality of variance and Student's $t$-test for independent samples were used. All experimental data were expressed as means \pm standard deviation $(\mathrm{M} \pm \mathrm{SD})$. The difference between groups was defined to be statistically significant at $P \leq 0.05$.

\section{Results and Discussion}

With the development of obesity, there are changes in the functioning of the immune system, both at the local - in hypertrophied adipose tissue and at the systemic levels, which gives reason to regard obesity as a chronic mild inflammatory condition. Such disorders are associated with increased tissue and serum concentrations of proinflammatory cytokines (TNF $\alpha$, IL-1b, IL-6, IFN $\gamma$ ), which cause various biological effects, such as adequate immune response by the relationship between nonspecific protective reactions and specific immunity. It is shown that with increasing the degree of obesity decreases the absolute number of T-lymphocytes and their functional activity, increases the absolute number of B-lymphocytes, increases the level of granulocytes and monocytes. The established imbalance in the immune system of obese patients involves the processes of maturation and differentiation of lymphocytes, increases the cytotoxic activity of immunocompetent cells, increases the expression of receptors for cytokines, activates apoptosis [9]. In the future, macrophages contribute to the adipocytes hypertrophy accompanied by an increase in their functional activity and increased inflammatory response [10].

There are functional changes in the lymphoid organs. When studying the structural changes in the thymus and spleen under conditions of prolonged high-calorie load, previous studies have shown that lymphoid organs respond differently to long-term use of high-calorie diets. In the animals of the HCD group, in the thymus tissue, vascular disorders and high proliferative activity of lymphocytes in the cortical and cerebral matter were observed. In the spleen of animals under such conditions, there was a significant decrease in the volume of white pulp, a reduced content of lymphoid elements, noted vascular disorders [11].

It has been proven [12], that nitric oxide, which is formed by numerous cells involved in the immune response and participates in almost every stage of pathology development, plays a key role in the regulation of the immune responses of organism. NO can have both pro- and anti-inflammatory effects.

In the study of the state of nitric oxide system in the lymphoid cells of the thymus and spleen of rats under experimental obesity, it was established that under conditions of high-calorie diet in the cells of the animals immune organs nitric oxide content decreased compared to control. Indicators had a similar tendency to decrease: in the lymphocytes of the spleen, the NO content was statistically lower than in the control by 1.4 times, in thymocytes -1.3 times (Fig. 1).

One of the potential mechanisms that can lead to a decrease in NO levels in the lymphoid cells of rats with experimental obesity is its increased decay as a result of excessive production of superoxide. The superoxide anion eliminates NO, resulting in a potent oxidant peroxynitrite, which can cause significant cell dysfunction, including mitochondrial dysfunction, and lead to necrosis or apoptotic cell death. Study [13] has shown that in apoptosis, the activity of xanthine oxidase and the conversion of the xanthine dehydrogenase into xanthine oxidase, the functioning of which is one of the main sources of superoxide in thymus cells, significantly increased in thymocytes, that, at the same time, significantly activates the process of lipid peroxidation (LPO). There is evidence to suggest that NO can, in contrast, reduce the incidence of cell apoptosis by thiolmediated caspase inactivation, attenuate the cytotoxic effect of the superoxide anion radical, the LPO process, and other factors [14].

At the same time, the action of a number of factors (increased cholesterol, low-density lipoprotein (LDL), high glucose concentrations, ischemia, etc.) that occur at dyslipidemia observed in obesity, can cause a decrease in NO production due to inhibition of NOS, and reducing its expression [15].

Against the background of a decrease in the content of NO in the lymphoid cells of rats, inhibition of NOS activity in splenocytes of animals on a 

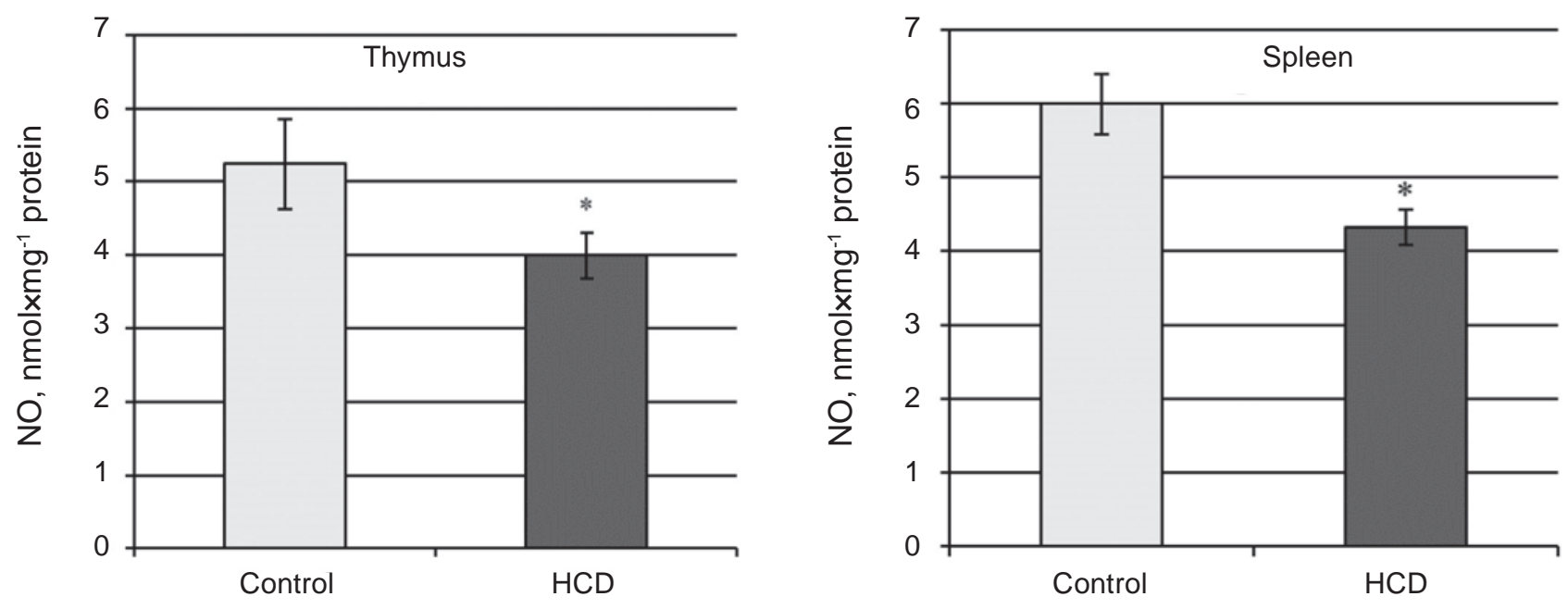

Fig. 1. Nitric oxide content in lymphoid cells of thymus and spleen of rats under conditions of diet-induced obesity $(M \pm S D, n=10)$. ${ }^{*} P<0.05$ compared to control group

high-calorie diet was found in 6.7 times compared to the control. No statistically significant changes in enzymatic activity were observed in thymocytes under such conditions (Fig. 2).

It has been shown [16] that under conditions of obesity, the high proliferative activity which is characteristic for the lymphocytes of the thymus cortical layer can be balanced by the death of some cells, as well as their accelerated release into the blood and peripheral immune organs, including the spleen.

It is known that the constitutive NOS isoforms are constantly expressed in thymocytes, although the expression of an inducible form of the enzyme is possible in the epithelial and dendritic cells of the

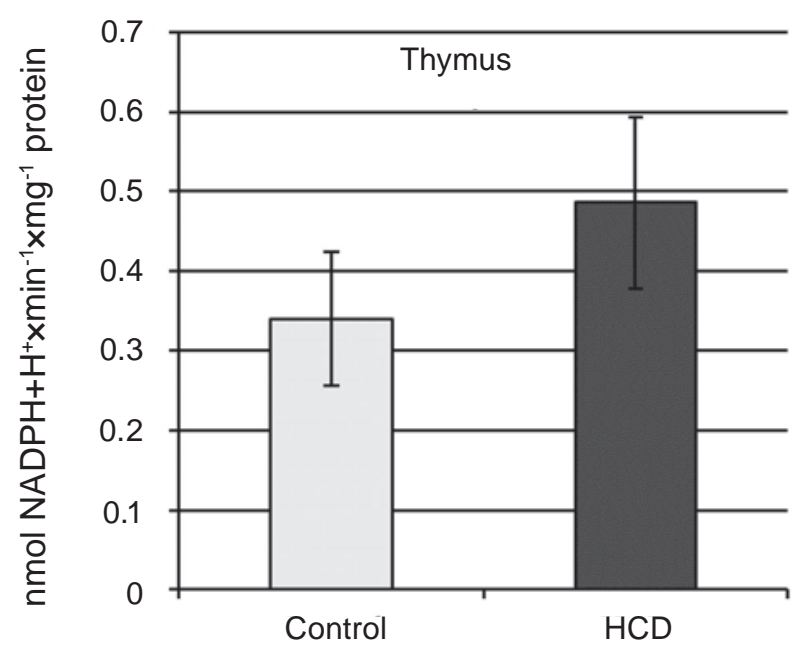

connective tissue of the thymus. However, eNOS produces low concentrations of NO [17].

The production of NO in immunocompetent cells completely depends on the presence of a substrate for NOS - L-arginine, the synthesis and transport of which from blood plasma is reduced in obesity, and catabolic processes are intensified. The established decrease in NO-synthase activity in the splenocytes of rats on a high-calorie diet may be due to impaired bioavailability of intracellular Larginine, as most cell types are unable to synthesize it and require exogenous intake.

L-arginine regulates multiple metabolic processes associated with the metabolism of fatty acids,

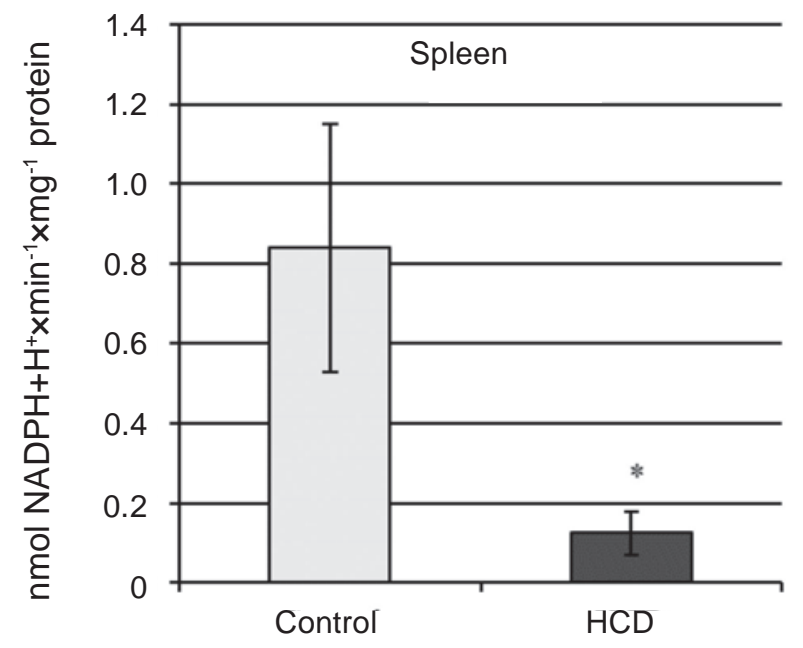

Fig. 2. Nitric oxide synthase activity in lymphoid cells of thymus and spleen of rats under conditions of dietinduced obesity $(M \pm S D, n=10)$. $* P<0.05$ compared to control group 
glucose, amino acids and proteins, cross-interactions between adipocytes and muscles; enhances the expression and activity of AMP-activated protein kinase, thereby modulating energy balance and lipid metabolism in the direction of reducing the amount of triacylglycerides. Immune cells use L-arginine in NO synthesis (through iNOS) to enhance cellular immune function by modulating cytokine production as well as lymphocyte proliferation and differentiation [18]. It is important to note that NO-synthase belongs to the group of oxidases, which under certain conditions, for example, in the absence of substrate (L-arginine) or cofactors (especially BH4), is able to synthesize superoxide anion instead of NO or simultaneously synthesize both of these products, which is a prerequisite for the formation of peroxynitrite. It is established that all active forms of NO inhibit the functional activity of NOS during catalysis. It has been suggested that neuronal NOS undergoes autoinhibition by endogenously generated NO molecules or the nitroxyl anion $\mathrm{NO}^{-}$[19].

Such data on the parameters of the nitric oxide system in the lymphoid cells of the spleen and thymus of rats with experimental obesity may indicate changes in the functional activity of lymphocytes caused by metabolic disorders of the organism, or may be mediated through other regulatory cellular mechanisms.

Obesity is a multisystem disease, which includes almost all tissues and organs. The nitric oxide system can be considered one of the most important regulators of the general adaptive capabilities of the organism, ensuring its optimal operation.

Further studies showed an increase in NO-synthase activity (2-times) and NO content (1.5-times) in the rats blood serum of the HCD group compared to control animals (Table). This increase in the parameters of the NO system may be evidence of the development of a mild inflammatory process in the organism caused by obesity. There is a synthesis of proinflammatory cytokines (IL-1, IL-6, TNF- $\alpha$ ), which can mediate the connection between the inflammatory process with low activity and metabolic disorders of the vascular endothelium and cause its dysfunction [20]. Under these conditions, an inducible macrophage form of NOS is activated, which synthesizes an increased amount of NO. Stimulation of the nitric oxide system in the blood can be regarded as a protective compensatory response aimed at removing irreversible changes in vascular endothelium, which plays an important role in regulating vascular tone, synthesis and inhibition of proliferation factors, maintenance of hemostasis, involved in local inflammation [21]. An imbalance in nitric oxide synthesis mediated by changes in the vascular endothelium can be the pathogenetic basis for many diseases, including obesity.

An important target organ in obesity is the liver, which is involved in the pathogenesis of insulin resistance and the steatohepatosis development. Steatosis ("fatty liver") is found in obese patients 4.6 times more often than in the general population. Liver function is determined by complex mechanisms of interaction of heterogeneous subpopulations of cells: hepatocytes, Kupffer cells, bile duct cells, tissue basophils, endothelial cells that form the liver. All these cells are capable of generating NO, which takes part in most metabolic processes occurring in the liver. It is suggested that NO is involved in the regulation of intercellular interactions in the liver, the processes of formation and secretion of bile, as well as nonspecific immune response [22].

Against the background of change parameters of the NO-ergic system in lymphoid organs and blood serum, the result of our studies showed a decrease of NOS activity (2.5 times compared to control) in the liver homogenate of rats in which dietinduced obesity was simulated (Table).

The nitric oxide content and nitric oxide synthase activity in blood serum and liver homogenate of rats under conditions of experimental obesity $(M \pm S D, n=10)$

\begin{tabular}{l|c|c|c|c}
\hline \multirow{2}{*}{$\begin{array}{c}\text { Experimental } \\
\text { state of animal }\end{array}$} & \multicolumn{2}{|c|}{ Serum } & \multicolumn{2}{c}{ Liver } \\
\cline { 2 - 5 } & $\begin{array}{c}\mathrm{NO}, \mathrm{nmol} \times \mathrm{mg}^{-1} \\
\text { protein }\end{array}$ & $\begin{array}{c}\mathrm{NOS}, \mathrm{nmol} \\
\mathrm{NADPH}+\mathrm{H}^{+} \times \mathrm{min}^{-1} \times \mathrm{mg}^{-1} \\
\text { protein }\end{array}$ & $\begin{array}{c}\mathrm{NO}, \mathrm{nmol} \times \mathrm{mg}^{-1} \\
\text { protein }\end{array}$ & $\begin{array}{c}\text { NOS, nmol } \\
\mathrm{NADPH}+\mathrm{H}^{+} \times \mathrm{min}^{-1} \times \mathrm{mg}^{-1} \\
\text { protein }\end{array}$ \\
\hline Control & $1.49 \pm 0.17$ & $0.13 \pm 0.04$ & $4.17 \pm 0.46$ & $0.33 \pm 0.04$ \\
HCD & $2.18 \pm 0.25^{*}$ & $0.27 \pm 0.05^{*}$ & $5.89 \pm 0.49^{*}$ & $0.13 \pm 0.04^{*}$ \\
\hline
\end{tabular}

$* P<0.05$ compared to control group 
It is known that in the liver, NO is formed mainly under the action of two isoforms of NOS eNOS and iNOS. The level of expression and activity of NOS proteins in a healthy organ and in pathology are different. Decreased NOS activity in the liver of rats with obesity may be result of cellular division of the constitutive form of NO-synthase (eNOS) and its translocation into nucleus of hepatocytes [23]. An increase in NO concentration in blood as a result of iNOS activation by the feedback mechanism can induce a sharp inhibition of eNOS expression, which confirms the results of immunohistochemical studies of A. I. Sarela et al., which showed a significant decrease in the activity of this form of enzyme in patients with liver cirrhosis [24]. Inhibition of the endothelial form of NO-synthase and increased destruction of NO leads to a decrease in bioavailable nitric oxide, which is important in the developingt endothelial dysfunction in obesity.

It should be noted that both constitutive and inducible isoforms of NOS are related to the production of NO in the early phase of inflammation, with their proinflammatory effect. The late phase of inflammation is associated with local leukocyte activity and infiltration. Only NO produced with the participation of iNOS localized in leukocytes is involved in its development [25]. It is shown that in hepatocytes, the expression of iNOS was carried out only in the presence of Kupffer cells stimulated with lipopolysaccharide, $\gamma$-INF, tumor necrosis factor, IL-1 [26].

However, despite the decrease in NOS activity, the NO content in the liver tissue of animals with experimental obesity increased (1.4 times compared to control values), which is possible due to high reserve-adaptive capacity of the body and cyclic metabolism of NO. In particular, it is known that in liver tissue, it can be realized at the expense of cytochrome oxidase in mitochondria and cytochrome P450 microsomes, which, interacting with oxygen in deoxyform, can reduce $\mathrm{NO}_{2}^{-}$in $\mathrm{NO}$ [27].

Conclusion. Thus, research has shown changes in functional state of the nitric oxide system in immunocompetent cells of thymus and spleen, in the blood serum and liver homogenate of rats with HCD-induced obesity. The study of the peculiarities of the immune system functioning under conditions development of metabolic disorders, among which obesity is important, is necessary not only to understand the patterns of development of the pathological process, but also to predict the course of comorbidities.
Conflict of interest. Authors have completed the Unified Conflicts of Interest form at http://ukrbiochemjournal.org/wp-content/uploads/2018/12/ coi_disclosure.pdf and declare no conflict of interest.

Funding. The study was conducted with the support of the research laboratory "Physical and Chemical Biology" Educational and Scientific Centre "Institute of Biology and Medicine" of Taras Shevchenko National University of Kyiv within the research topic No 11BF036-01.

\section{NO-СИНТАЗНА АКТИВНІСТЬ ТА ВМІСТ ОКСИДУ АЗОТУ В ЛІМФОЇДНИХ КЛІТИНАХ ТИМУСА ТА СЕЛЕЗІНКИ ЩУРІВ ЗА ОЖИРІННЯ, ІНДУКОВАНОГО ДІЕТОЮ}

\section{Л. Кот ${ }^{\bowtie}$, В. Конопельнюк, К. Дворщенко, B. Верещака}

\author{
ННЦ «Інститут біології та медицини», \\ Київський національний університет \\ імені Тараса Шевченка, Україна; \\ 凶e-mail: kot_lora@ukr.net
}

Відомо, що порушення метаболічних процесів за ожиріння супроводжуються системним запаленням та дисбалансом імунної системи, і що система оксиду азоту (NO) $є$ однією $з$ ключових ланок у регуляції імунних реакцій організму. Метою роботи було оцінити NO-синтазну (NOS) активність та вміст NO у клітинах тимуса та селезінки щурів за ожиріння, індукованого 14-тижневою висококалорійною дієтою. Вміст NO в клітинних суспензіях визначали за допомогою реактива Гріса, NO-синтазну активніть - за специфічним розщепленням $\mathrm{NADPH}^{+}+\mathrm{H}^{+}$. Показано, що за експериментального ожиріння тварин вміст NO в клітинах тимуса і селезінки та активність NOS у селезінці знижувались у разі одночасного збільшення вмісту NO та активності NOS у сироватці крові. Одержані дані свідчать про зміни функціональної активності лімфоїдних клітин та загальної адаптаційної здатності організму за ожиріння.

Ключов і слова: оксид азоту, NOS, лімфоїдні клітини, дієтіндуковане ожиріння. 


\section{References}

1. Yarosz EL, Chang CH. The role of reactive oxygen species in regulating $\mathrm{T}$ cell-mediated immunity and disease. Immune Netw. 2018; 18(1): e14.

2. Weitman ES, Aschen SZ, Farias-Eisner G, Albano N, Cuzzone DA, Ghanta S, Zampell JC, Thorek D, Mehrara BJ. Obesity impairs lymphatic fluid transport and dendritic cell migration to lymph nodes. PLoS One. 2013; 8(8): e70703.

3. Gantner BN, LaFond KM, Bonini MG. Nitric oxide in cellular adaptation and disease. Redox Biol. 2020; 34: 101550.

4. Shen XH, Tang QY, Huang J, Cai W. Vitamin $\mathrm{E}$ regulates adipocytokine expression in a rat model of dietary-induced obesity. Exp Biol Med (Maywood). 2010; 235(1): 47-51.

5. Morozov VG, Havinson VH. Immunological function of the thymus. Usp Sovrem Biol. 1985; 99(1): 36-37. (In Russian).

6. Böyum A. Separation of leukocytes from blood and bone marrow. Introduction. Scand J Clin Lab Invest Suppl. 1968; 97: 7.

7. Sumbayev VV, Yasinskaya IM. DDT effect on rat liver, lungs and brain nitric oxide synthasc activity. Modern Problems Toxicol. 2000; (3): 3-7. (In Russian).

8. Kiselyk IO, Lutsyk MD, Shevchenko LYu. Features of determination of nitrates and nitrites in peripheral blood in patients with viral hepatitis and jaundice syndrome of other etiology. Lab Diagn. 2001; (3): 43-45. (In Ukrainian).

9. Moro-García MA, Mayo JC, Sainz RM, Alonso-Arias R. Influence of inflammation in the process of $\mathrm{T}$ lymphocyte differentiation: proliferative, metabolic, and oxidative changes. Front Immunol. 2018; 9: 339.

10. Keuper M. On the role of macrophages in the control of adipocyte energy metabolism. Endocr Connect. 2019; 8(6): R105-R121.

11. Yakubtsova IV, Hilko TD, Savitskaya IM. Influence of Trigonella foenum graecum L. on the state of immunocompetent organs under conditions of diet-induced obesity in rats. ScienceRise Biol Sci 2016; 3(3): 53-60. (In Ukrainian).

12. Shreshtha S, Sharma P, Kumar P, Sharma R, Singh SP. Nitric oxide: it's role in immunity. J Clin Diagn Res. 2018; 12(7): BE01-BE05.
13. Kishko TO, Dmitrenko NP. Role of xanthine oxidase and xanthine dehydrogenase systems in thymocyte apoptosis, induced by papaverine. Ukr Biokhim Zhurn. 2000; 72(3): 95-104. (In Russian).

14. Murphy MP. Nitric oxide and cell death. Biochim Biophys Acta. 1999; 1411(2-3): 401-414.

15. Feron O, Dessy C, Moniotte S, Desager JP, Balligand JL. Hypercholesterolemia decreases nitric oxide production by promoting the interaction of caveolin and endothelial nitric oxide synthase. J Clin Invest. 1999; 103(6): 897905.

16. Yang H, Youm YH, Vandanmagsar B, Ravussin A, Gimble JM, Greenway F, Stephens JM, Mynatt RL, Dixit VD. Obesity increases the production of proinflammatory mediators from adipose tissue $\mathrm{T}$ cells and compromises TCR repertoire diversity: implications for systemic inflammation and insulin resistance. J Immunol. 2010; 185(3): 1836-1845.

17. Aiello S, Noris M, Piccinini G, Tomasoni S, Casiraghi F, Bonazzola S, Mister M, Sayegh MH, Remuzzi G. Thymic dendritic cells express inducible nitric oxide synthase and generate nitric oxide in response to self- and alloantigens. J Immunol. 2000; 164(9): 4649-4658.

18. Kim SH, Roszik J, Grimm EA, Ekmekcioglu S. Impact of L-arginine metabolism on immune response and anticancer immunotherapy. Front Oncol. 2018; 8: 67.

19. Kotsonis P, Frey A, Fröhlich LG, Hofmann H, Reif A, Wink DA, Feelisch M, Schmidt HH. Autoinhibition of neuronal nitric oxide synthase: distinct effects of reactive nitrogen and oxygen species on enzyme activity. Biochem J. 1999; 340(Pt 3): 745-752.

20. Kwaifa IK, Bahari H, Yong YK, Noor SM. Endothelial dysfunction in obesity-induced inflammation: molecular mechanisms and clinical implications. Biomolecules. 2020; 10(2): 291.

21. Vanhoutte PM. Endothelial dysfunction: the first step toward coronary arteriosclerosis. Circ J. 2009; 73(4): 595-601.

22. Iwakiri Y, Kim MY. Nitric oxide in liver diseases. Trends Pharmacol Sci. 2015; 36(8): 524-536.

23. Rafikov R, Fonseca FV, Kumar S, Pardo D, Darragh C, Elms S, Fulton D, Black SM. eNOS activation and NO function: structural motifs responsible for the posttranslational control 
of endothelial nitric oxide synthase activity. J Endocrinol. 2011; 210(3): 271-284.

24. Sarela AI, Mihaimeed FM, Batten JJ, Davidson BR, Mathie RT. Hepatic and splanchnic nitric oxide activity in patients with cirrhosis. Gut. 1999; 44(5): 749-753.

25. Smirnov VV, Gorbunov GE. The role of nitric oxide in the physiology and pathology of organs and systems. Pediatrics. 2010; 89(6): 182-188.
26. Sass G, Koerber K, Bang R, Guehring H, Tiegs G. Inducible nitric oxide synthase is critical for immune-mediated liver injury in mice. $J$ Clin Invest. 2001; 107(4): 439-447.

27. Sarti P, Giuffré A, Forte E, Mastronicola D, Barone MC, Brunori M. Nitric oxide and cytochrome c oxidase: mechanisms of inhibition and NO degradation. Biochem Biophys Res Commun. 2000; 274(1): 183-187. 